\title{
Greek Hydropower Production and The European Union (EU) Water Framework Directive: Potentially Conflicting Interests and Sustainable Governance of River Basins
}

\author{
Polytimi Michael Farmaki ${ }^{1, *}$, Apostolos Charalampos Tranoulidis ${ }^{2}$ \\ 1 Department of Accounting and Finance, University of Western Macedonia, Kila Kozani, 50100 Greece \\ 2 Department of Environmental Engineering, University of Western Macedonia, Kila Kozani, 50100 Greece; \\ atranoulidis@uowm.gr \\ * Correspondence: pmfarmaki@gmail.com
}

\begin{abstract}
Hydropower-based electricity production provides approximately $23 \%$ of renewable energy in Greece - an activity, however, associated with adverse environmental effects on watercourses. Therefore, it should be considered as a key factor of water management programs ensuring safety and optimising environmental performance of hydropower facilities in accordance to Greece's obligations towards European Union (EU) water policy. Water Framework Directive (WFD) was created by the EU in order to help member states to protect and improve the status of water bodies and was incorporated in Greek legislation by Law 3199/2003. Within the scope of this study, we assessed 1. both Hydroelectric power generation and Water Resources Management in Greece and we recorded the 2. current status of the EU Water Framework Directive implementation in this field. Given that social-ecological systems emphasise the link between people and the ecosphere, we investigated possible 3. conflicts that arise between hydropower-related renewable electricity production and water courses conservation, according to both national and EU legislation. 4. We also studied the tools that WFD provides in order to solve potential problems, maintain economic viability and ensure good ecological status between hydropower utilisation and water protection in the face of increased demands to a more effective and sustainable management of environmental resources.
\end{abstract}

Keywords: water management in EU; Water Framework Directive; hydropower energy; good ecological potential; renewable energy resources; ecosystem

\section{Introduction}

Climate change is already affecting water availability. According to the European Environmental Bureau' s (EEA) report, "Northern Europe has generally become wetter in recent decades (up to $70 \mathrm{~mm}$ per decade), whereas southern Europe has generally become drier (up to $90 \mathrm{~mm}$ per decade). "Decreasing river flows are projected for southern European countries (particularly Cyprus, Greece, Italy, Malta, Portugal, Spain and Turkey) and increasing flows for northern European countries." As the EEA points out, these changes will impact hydropower production and challenge hydropower storage capacities with the risk of power outages [1].

Today hydropower plants are contributing towards European Union (EU) energy targets for 2020-2030 playing a key role in Renewable Energy Directive implementation and $\mathrm{CO}_{2}$ emissions reduction as they do not pollute the air like power plants. However, they have many negative effects on biodiversity, river flows and aquatic communities as they cause changes in river morphology and riverine habitats.

Water Framework Directive (WFD) is the key point of the institutional framework of the third phase of European's Union water resources management and its purpose is to establish a framework for the protection of inland surface waters, transitional waters, coastal waters, and groundwater 
(Article 1). This provision indicates the intention of the EU to establish an integrated management policy for all water resources in relation to the previous directives dealing with the issue fragmentally and individually [2]. It also promotes sustainable water use based on protection of available water resources, ensures the progressive reduction of pollution of groundwater, and prevents its further pollution and aims at enhanced protection and improvement of the aquatic environment, inter alia. This means that WFD sets environmental objectives considering economic development as well as social effects and geographic and climatic conditions.

The use of water to generate power goes back centuries, with water wheels being used since the times of ancient Greece. Urban water management in ancient Greece resulted in many constructions and during oligarchic periods the emphasis was on the construction of large-scale hydraulic projects. In Greece, the first dam was built in ancient Alyzia (between 1st and 5th century BC)[3-4] which was constructed in distinct stages aiming to reduce the coarse sediments of the Varnakas stream deposited on the cultivated Mytikas plain.

According to the data given from Greek Committee on Large Dams [5] the table below contains the Public Power Center dams that produce hydroelectric energy:

Table 1. List of large Greek dams for the purpose of electricity generation alphabetical order based on data of HELLENIC COMMITTEE OF LARGE DAMS.

\begin{tabular}{|c|c|c|c|c|c|}
\hline $\mathbf{A} / \mathbf{A}$ & NAME & $\begin{array}{c}\text { YEAR OF } \\
\text { CONSTRUCTION }\end{array}$ & $\begin{array}{l}\text { CONSTRUCTION } \\
\text { OPERATOR }\end{array}$ & HEIGHT & $\begin{array}{l}\text { DISTRICT or } \\
\text { COUNTRY }\end{array}$ \\
\hline 1 & $\begin{array}{c}\text { AGIA } \\
\text { VARVARA }\end{array}$ & 2007 & PPC-DEI & 20 & IMATHIA \\
\hline 2 & ASOMATA & 1985 & PPC-DEI & 52 & IMATHIA \\
\hline 3 & $\begin{array}{c}\text { DAFNOZONAR } \\
\text { A }\end{array}$ & 2010 & $\begin{array}{c}\text { TERNA } \\
\text { ENERGIAKI }\end{array}$ & 28 & AITOLOAKARNANIA \\
\hline 4 & THISAVROS & 1996 & PPC-DEI & 172 & DRAMA \\
\hline 5 & ILARIONAS & 2012 & PPC-DEI & 130 & KOZANI \\
\hline 6 & KASTRAKI & 1969 & PPC-DEI & 96 & AITOLOAKARNANIA \\
\hline 7 & KREMASTRA & 1965 & PPC-DEI & 165 & AITOLOAKARNANIA \\
\hline 8 & LADONAS & 1955 & PPC-DEI & 56 & ARKADIA \\
\hline 9 & LOUROS & 1954 & PPC-DEI & 22 & PREVEZA \\
\hline 10 & MESOBOYNOY & 2009 & $\begin{array}{l}\text { PREFECTURE OF } \\
\text { KOZANI }\end{array}$ & 32 & KOZANI \\
\hline 11 & MESOXORA & 2009 & PPC-DEI & 150 & TRIKALA \\
\hline 12 & METSOBITIKOS & 2011 & PPC-DEI & 11 & IOANNINA \\
\hline 13 & PIGES AOOU & 1999 & PPC-DEI & 78 & IOANNINA \\
\hline 14 & PLATANOBRISI & 1998 & PPC-DEI & 95 & DRAMA \\
\hline 15 & POLIFITO & 112 & PPC-DEI & 112 & KOZANI \\
\hline 16 & POURNARI & 1981 & PPC-DEI & 87 & ARTA \\
\hline 17 & POURNARI II & 1998 & PPC-DEI & 15 & ARTA \\
\hline 18 & PRAMORITSA & 2007 & $\begin{array}{c}\text { PREFECTURE OF } \\
\text { KOZANI }\end{array}$ & 57 & KOZANI \\
\hline
\end{tabular}




\begin{tabular}{cccccc}
\hline 19 & SISANIOU & 2006 & $\begin{array}{c}\text { PREFECTURE OF } \\
\text { KOZANI }\end{array}$ & 35 & KOZANI \\
\hline 20 & SMOKOBO & 1996 & Y.ПE.X $\Omega . \Delta . E^{*}$ & 109 & KARDITSA \\
\hline 21 & STRATOS & 1988 & PPC-DEI & 26 & AITOLOAKARNANIA \\
\hline 22 & SIKIA & 2013 & Y.ПE.X $\Omega . \Delta . E^{*}$ & 170 & TRIKALA-KARDITSA \\
\hline 23 & SFIKIA & 1985 & PPC-DEI & 82 & IMATHIA \\
\hline 24 & TAYROPOS & 2006 & PPC-DEI & 83 & KARDITSA \\
\hline
\end{tabular}

Except from these dams there are many other dams that serve irrigation and water supply which were constructed by the Ministry of Agriculture such as dams Apo, Akkias Rhodes (1989), Lefkogion Drama (1994), Doxa Feneou Korinthias (1996) and Livadiou Astypalea (1997).

The objective of this study was to assess both Hydroelectric power generation and Water Resources Management in Greece considering the conflicts that arise between hydropower-related electricity production and water courses conservation. The work was based on data collection and analysis of hydropower in Greece, literature review and analysis of the legislation for watercourses resources both in Greece and the EU?

The paper is structured as follows: The first part describes the methodological approach adopted in the study, the second part presents the results of our data analysis for Greek Hydropower Production, Definitions of the Water Framework Directive and Greek legislation on water resources protection. The third part discusses the challenges to ensure good ecological potential and faces the conflicts between hydropower utilisation and water protection.

\section{Materials and Methods}

Available data on Greek Hydropower Production, Definitions of the Water Framework Directive, Greek legislation on water resources protection and designation of heavily modified water bodies, were analysed to synthesize the current knowledge and resolve conflicts between water use for energy production and conservation of vulnerable water resources. The analysis was based on literature review and the study of the Greek legislation on Water Resources Protection.

The approach that we developed is organised in three steps: 1) Hydroelectric power generation in Greece (Section 3.1) 2) definitions of hydropower utilisation and water protection at WFD 2000/60 (Section 3.2); 3) designation of heavily modified water bodies within the context of WFD implementation in Greece (Section 3.3).

\section{Results}

\subsection{Hydropower today}

Hydropower-based electricity production provides approximately $23 \%$ of renewable energy in Greece (2019)- an activity, however, associated with adverse environmental effects on watercourses. Renewable energy sources include wind, hydroelectric, solar, biofuels and waste. 


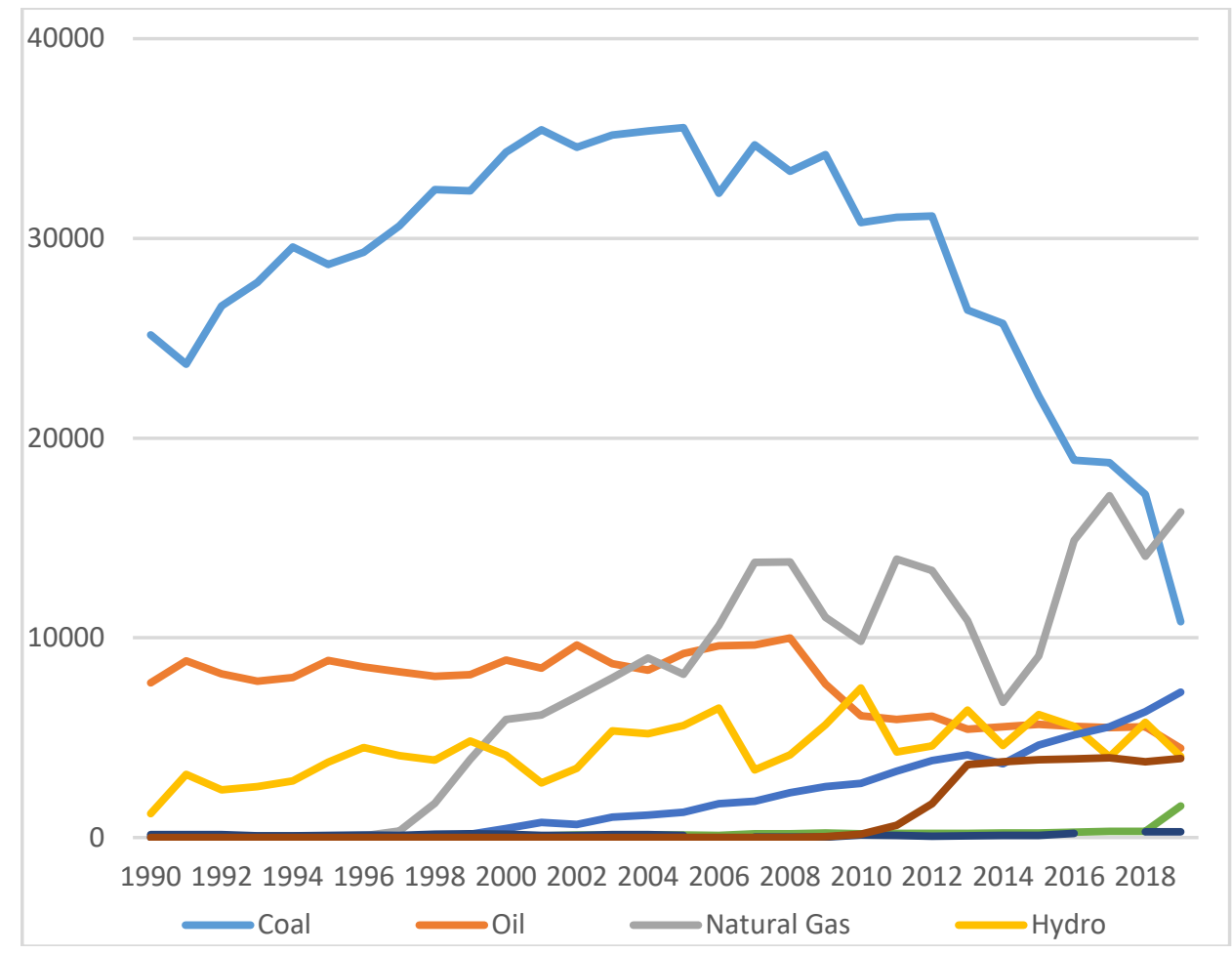

Figure 1. Electricity generation by Source in Greece 1990-2019, Source of data: IEA.

Figure 1 shows the sources of total energy installed capacity in Greece from 1990 to 2019. The most notable element is the omnipotence of lignite in the country which however, began to fall gradually from 2005 onwards. According to the National Energy and Climate Plan (ESEK) lignitefueled energy is expected to reach $0 \%$ in 2028. In 2019, natural gas was the largest contributor to energy generation, surpassing coal in 2018. There is a downward trend in oil, which started in 2008 and stabilized in 2010 at lower levels. Biofuels and waste are at almost zero levels, with a small weak increase in 2018.

Hydroelectric-powered energy share remains steady while wind and solar energy production show an increasing trend. The most interesting statistic in Hydroelectric-powered energy is the contribution of hydroelectric installed capacity for 2019 in Greece, which accounts towards $8.4 \%$ of the total installed capacity in Greece that amounted to $48,742 \mathrm{GWh}$. More specifically, the energy supply share consisted of coal/lignite (10,805 GWh), oil (4,471GWh), natural gas $(16,303 \mathrm{GWh})$, hydroelectric power $(4,059 \mathrm{GWh})$, wind energy (7,278 GWh), biofuels (1,579 GWh), waste incineration $(0.29 \mathrm{GWh})$ and photovoltaic / solar PV (3,961GWh).

According to the data given at Figure 2 the percentage of installed power of hydroelectric energy, among renewable energy sources amounts to 27\% in Greece for 2019. 


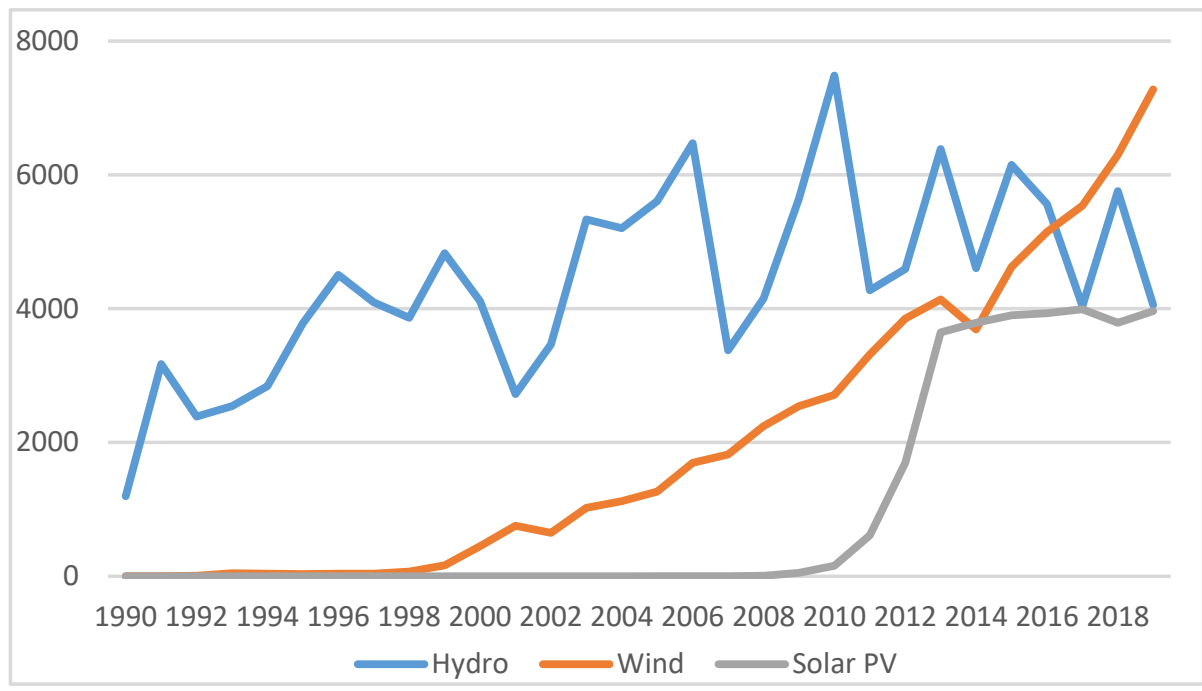

Figure 2. Renewable electricity generation by source for Greece 1990-2019, Source of data: IEA.

Figure 2 represents the evolution of the installed capacity of the three main renewable energy sources, hydroelectric, wind and solar energy from 1990 to 2019. It is observed that hydroelectric power shows constant fluctuations and a relatively stable central trend from 2000 to and 2019. Wind energy started in 1998 with a steady upward trend until 2019, while solar energy started at a very fast pace from 2010 to 2013, followed by a stable plateau until 2019 while it is expected to increase significantly in the coming years due to of the overall energy policy that Greece will follow.

\subsection{The Water Framework Directive 2000/60: hydropower utilisation and water protection}

The Community's institutional framework of water resources management and protection was developed in three phases. The Water Framework Directive 2000/60 is the main tool of the third phase as it incorporates a more coherent policy and explicitly determines for the first time, the scope of the new legal framework for protection of surface, transitional, coastal and groundwater (Article 1).[6] The main environmental objectives of the Directive are in particular to achieve "good ecological and good chemical status" for surface water bodies in general and "Good ecological potential" as the status of a heavily modified or an artificial body of water by 2015. The WFD also requires the reduction and ultimate elimination of priority hazardous substances and the reduction of priority substances to below set quality standards.

According to No 23 of Article 2: "Heavily modified water body, means a body of surface water which as a result of physical alterations by human activity is substantially changed in character, as designated by the Member State in accordance with the provisions of Annex II." and member States may designate a body of surface water as artificial or heavily modified, when (Article 4 paragraph 3) : (a) the changes to the hydromorphological characteristics of that body which would be necessary for achieving good ecological status would have significant adverse effects on:

i)

ii)

(iii) activities for the purposes of which water is stored, such as drinking-water supply, power generation or irrigation".

According to Article 4.7 of the WFD, exemptions can be approved by the authorities for new modifications and sustainable human development activities that result in the deterioration of the status of the water body or that prevent the achievement of good ecological status or potential, or good groundwater status under certain conditions. This potentially includes new developments related to hydropower.[7] According to these provisions all hydropower installations and projects are subject to environmental provisions of WFD to ensure their sustainability. 
There are many environmental regulations and Directives that have a complementary role to the WFD regarding watercources protection, restoration of Europe's freshwater ecosystems and design, construction and operation of hydropower installations. Hydropower must conform to the requirements of WFD and legal requirements that are laid down at the Nature Directives (92/43/ EEC -preservation of natural habitats and the flora and fauna therein, the EU flora, fauna and habitat (FFH) directive, 79/409/EEC- bird protection), the Floods Directive ,Directive 2001/77/EC on the promotion of electricity produced from renewable energy sources in the internal market (RES-E directive), 2001/77/ EC (furtherance of renewable energy development), and 2003/35/EC (environmental impact assessments for specific projects) [8].

\subsection{Designation of heavily modified water bodies in Greek legislation in accordance with WFD}

The harmonization of Greek legislation with the Community Framework Directive 2000/60 / EC was conducted with the Law 3199/2003 on "Water Protection and Management - Harmonization with Directive 2000/60/EC of the European Parliament and the Council of $23^{\text {rd }}$ October 2000", the Presidential Decree 51/2007 (Goverment Gazzete 54/ㄹ/A/08.03.2007) and the Joint Ministerial Decision 146896/2014 (Government Gazette B' 2878), “Categories of licenses for the use and execution of water utilization projects. Procedure and conditions for issuing licenses, their content and duration and other relevant provisions."

The main objectives of Law 3199/2003 which is divided in six basic chapters are:

- long-term protection of water resources, the prevention of deterioration and the protection and restoration/remediation of degraded water resources and wetlands,

- reduction and, in cases, the phase out of harmful and polluting discharges,

- reduction of groundwater pollution and the prevention of its further deterioration as well as the mitigation of the effects of floods and droughts.

Law 3199/03 has also incorporated the 'polluter pays principle' and the 'good ecological status or potential' for all water resources and has provided a detailed identification of 13 River Basin Districts (RBDs) according to the administrative units of the country. The active involvement of the interested parties is ensured by their representation at the National and Regional Water Councils and the incorporation of the public participation requirements of the WFD [2].

At a central level, Law 3199/2003 provided for the establishment of a National Water Board, a National Water Council (Article 3) and a Central Water Authority (Article 4). With regard to the development of the River Basin Management Plans, the national competent authority, the "Special Secretariat for Water" is responsible for coordination of water management issues; implementation of the WFD; monitoring of water quality and quantity; management and reuse of wastewater; floods management according to the Presidential Decree 24/2010 OJ A 56/15.04.2010 and Law 3199/2003 [9]. At decentralized level the 7 Decentralized Administrations and the 13 self-governed Regions are identified as Competent Authorities and they share the responsibilities.

Article 10 provides for the various water use and water supply subheadings; it provides that this is prioritized against any other use, i.e. irrigation, industrial use, energy use and recreational use. This article also makes the sole reference to the entire legislative text on the energy use of water, a very vital factor in Greece [10].

As far as it concerns hydropower-related electricity production and water resources protection according to WFD Article 4(3): Member States may designate a body of a surface water as artificial or heavy modified, when the changes to the hydromorphological characteristics of that body which would be necessary for achieving good ecological status would have significant adverse effect on activities for the purposes of which water is stored, such as power generation; Heavily modified water bodies are bodies of water which as a result of physical alterations by human activity are substantially changed in character and cannot, therefore, meet "good ecological status" (GES).

Greece has classified the HMWB's in accordance with the guidelines of the European Commission and the provisions of WFD beginning with an early stage identification of heavily modified water bodies and the measures need to be taken in order to achieve good status of the water body. The decision whether a water body is heavily modified or not is yet to be determined, therefore, 
at the Management Plans of the River Basins of Greek Districts environmental objective for HMWB and AWB is to achieve the 'good ecological potential' that corresponds to the type of natural water body to which it most closely resembles. The map below depicts the ecological potential of artificial and heavily modified bodies based on data of WISE, Eurostat and corrections/additions provided by EL in late 2014 [11] .

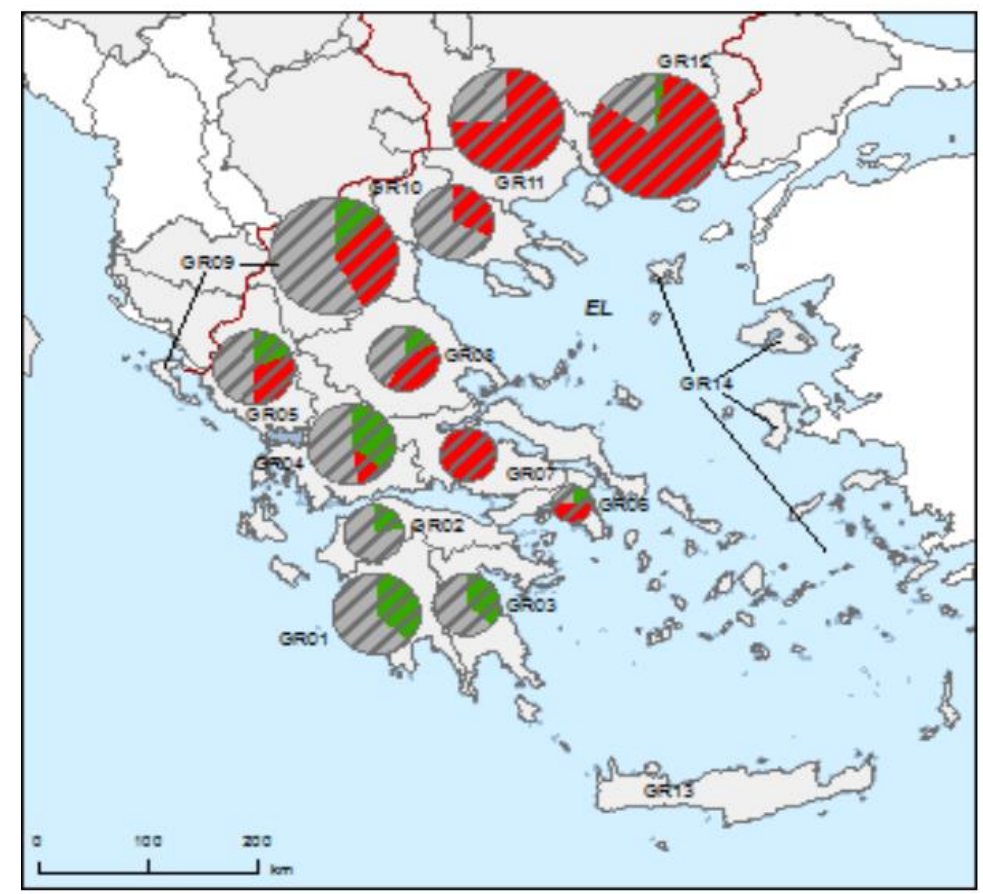

Good or better
Less than good
Unknown
River Basin Districts
Countries outside EU

Figure 3. Map of the ecological potential of artificial and heavily modified bodies.

According to data of Kanakoudi's article on progress regarding the River Basin Management Plans (RBMPs) in Greece 2014 (see the Table below), "......During the final delineation process for the HMWB and AWB, there is deficiency in information, measurements, adopted limits and reference conditions" [12].

Table 2. Overview of Implementation of Greek RBMR's.

\begin{tabular}{|c|c|c|c|c|c|c|c|c|c|c|c|c|}
\hline RBMP & $\begin{array}{c}\text { Public } \\
\text { Consultation }\end{array}$ & $\left|\begin{array}{l}\text { Competent } \\
\text { Authorities }\end{array}\right|$ & $\begin{array}{c}\text { SW'S } \\
\text { characterization } \\
\text { /typology }\end{array}$ & $\begin{array}{l}\text { Reference } \\
\text { Conditions }\end{array}$ & $\mid \begin{array}{l}\text { Significant } \\
\text { Pressures }\end{array}$ & $\begin{array}{c}\text { Protected } \\
\text { Areas }\end{array}$ & $\begin{array}{l}\text { Water } \\
\text { Pricing } \\
\text { Policies }\end{array}$ & Monitoring & $\begin{array}{c}\text { SW's } \\
\text { ecological/ } \\
\text { chemical } \\
\text { status }\end{array}$ & $\begin{array}{c}H M W B \\
A W B\end{array}$ & $\begin{array}{l}\text { Environmental } \\
\text { objective- } \\
\text { exemptions }\end{array}$ & PoM \\
\hline GR0I & Yes & Yes & Yes & Partly & Yes & Yes & Yes & Partly & Incomplete & Yes & Partly & Yes \\
\hline GR02 & Yes & Yes & Yes & Partly & Yes & Yes & Yes & Partly & Incomplete & Yes & Partly & Yes \\
\hline GR03 & Yes & Yes & Yes & $\begin{array}{l}\text { Partly } \\
\end{array}$ & Yes & Yes & Yes & Partly & Incomplete & Yes & Partly & Yes \\
\hline GR04 & Yes & Yes & Yes & Partly & Yes & Yes & Yes & Partly & Incomplete & Yes & Partly & Yes \\
\hline GR05 & Yes & Yes & Yes & Partly & Yes & Yes & Yes & Partly & Incomplete & Yes & Partly & Yes \\
\hline GR06 & Yes & Yes & Yes & Partly & Yes & Yes & Yes & Partly & Incomplete & Yes & Partly & \\
\hline \begin{tabular}{|l|} 
GR07 \\
\end{tabular} & Yes & Yes & Yes & Partly & Yes & Yes & Yes & Partly & Incomplete & Yes & Partly & \\
\hline GR08 & Yes & Yes & Yes & Partly & Yes & Yes & Yes & Partly & Incomplete & Yes & Partly & Yes \\
\hline GR09 & \multicolumn{12}{|c|}{ Drafts have been completed } \\
\hline GR010 & \multicolumn{12}{|c|}{ Drafts have been completed } \\
\hline GR011 & Yes & Yes & Yes & Partly & Yes & Yes & Yes & Partly & Incomplete & Yes & Partly & Partly \\
\hline GR012 & Yes & Yes & Yes & Partly & Yes & Yes & Yes & Partly & Incomplete & Yes & Partly & Partly \\
\hline GR013 & \multicolumn{12}{|c|}{ Consultations just started } \\
\hline GR014 & \multicolumn{12}{|c|}{ Consultations have not yet started } \\
\hline
\end{tabular}




\section{Discussion}

There are some aspects that are considered important in order to solve potential problems, maintain economic viability and ensure good ecological potential between hydropower utilisation and water protection. The transition from the general provisions of the Directive to its implementation in the HMWB is particularly difficult. There are ambiguities and questions that arise through legislation-implementation feedback.

So, the main conflict between hydropower production and the WFD arises a question whether to use water to produce renewable energy or to protect water resources and achieve good ecological potential. Understanding the linkages between the natural and socio-economic systems of HP electricity production can lead to improved and more sustainable management of ecosystems [13]. Hydropower, among other RES, is crucial in any transition towards low carbon energy solutions. There is an emergence of a new policy era with relation to HP to address the global challenge of climate change by using renewable energy systems and to facilitate the incorporation and expansion of other sources of renewable energy [14].

Adapting measures by implementing the provisions of WFD on good ecological potential and HMWB alongside with planning could minimise the environmental impacts by HP. However, legislation provisions and strict implementation of the WFD could cause potential conflict with the hydropower industry due to bureaucracy, smaller revenues, increasing of costs and reduction of HP production. But what about the aim of RES-directive to achieve $20 \%$ renewable energy by 2020 ? Does RES-directive and the WFD are contradicting each other? Table 3 [15] below gives an accurate answer to all these questions as it represents hydroelectric energy share in the energy mix of European countries. The largest percentage is observed in Albania, whose energy supply comes entirely from hydroelectric power, followed by Norway with $96 \%$. The last places are occupied by Hungary (1\%), Poland (2\%) and the United Kingdom (2\%).

Table 3. Ranking of European Countries by Hydro percentage in total energy production. Source of data: IHA 2018.

\begin{tabular}{|c|c|c|c|c|}
\hline \multirow{2}{*}{ Country } & \multicolumn{4}{|c|}{ Electricity Generation } \\
\hline & Hydro [GWh] & Total [GWh] & Hydro/Total \% & Main Energy Source \\
\hline European Union (28) & 38018 & $3.253,125$ & $12 \%$ & Nuclear, Coal, Gas \\
\hline Albania & 7.782 & 7.782 & $100 \%$ & Hydro \\
\hline Norway & 144.005 & 149.333 & $96 \%$ & Hydro \\
\hline Iceland & 13.471 & 18.55 & $73 \%$ & Hydro \\
\hline Austria & 42.919 & 68.336 & $63 \%$ & Hydro \\
\hline Switzerland & 36.689 & 63.172 & $58 \%$ & Hydro, Nuclear \\
\hline Sweden & 62.137 & 156.01 & $40 \%$ & Nuclear, Hydro \\
\hline North Macedonia & 1.897 & 5.629 & $34 \%$ & Coal, Hydro \\
\hline Bosnia and Herzegovina & 5.641 & 17.767 & $32 \%$ & Coal, HYdro \\
\hline Serbia & 11.521 & 39.342 & $29 \%$ & Coal, Hydro \\
\hline Portugal & 16.909 & 60.28 & $28 \%$ & Hydro, Coal, Gas, Wind \\
\hline Romania & 18.536 & 65.103 & $28 \%$ & Hydro, Goal, Nuclear, Gas \\
\hline Turkey & 67.231 & 273.695 & $25 \%$ & Coal, Gas, Hydro \\
\hline Slovak Republic & 4.606 & 26.934 & $17 \%$ & Nuclear, Hydro, Coal \\
\hline Russia & 186.64 & 1.090 .973 & $17 \%$ & Gas, Nuclear, Coal, Hydro \\
\hline
\end{tabular}




\begin{tabular}{ccccc}
\hline Spain & 39.865 & 274.671 & $15 \%$ & Nuclear, Gas, Wind \\
\hline Italy & 44.257 & 289.032 & $15 \%$ & Gas, Hydro, Coal \\
\hline France & 64.889 & 555.621 & $12 \%$ & Nuclear \\
\hline Greece & 5.565 & 54.438 & $10 \%$ & Coal, Gas \\
\hline Bulgaria & 4.568 & 45.243 & $10 \%$ & Coal, Nuclear \\
\hline Ukraine & 9.304 & 164.494 & $6 \%$ & Nuclear, Coal \\
\hline Germany & 26.135 & 647.231 & $4 \%$ & Coal, Gas, Nuclear, Wind \\
\hline United Kingdom & 8.354 & 339.399 & $2 \%$ & Gas, Nuclear \\
\hline Poland & 2.322 & 166.568 & $2 \%$ & Coal \\
\hline Hungary & 259 & 37.781 & $1 \%$ & Nuclear \\
\hline
\end{tabular}

There are many advantages of Hydroelectric power in comparison with other energy sources: $a$. It does not produce air pollutants and noise, $b$. it is a "clean" and renewable energy source saving foreign exchange and natural resources, c. it is an inexhaustible source of energy that helps to reduce dependence on conventional energy resources, $d$. reservoirs may meet needs related to water supply, irrigation, sports and e. despite their high construction costs most of the times the energy output absorbs this cost [16]. On the other hand, costly and time consuming completion of dams and environmental alterations in the area of the reservoir (possible movement of populations, degradation of areas, change in land use, in the flora and fauna of areas and the local climate, increase of seismic risk, etc.) are some of the disadvantages of hydropower production.

However, the conflict between water resources protection, good ecological potential of water and HP production in Greece still exists. Based on the information submitted by EL in late 2014, "....the water uses that are linked to the water bodies designated as HMWB as well as the types of physical modifications leading to the designation are mentioned briefly in most but not all RBDs, with differences regarding the way relevant information is presented in each group of RBMPs." Even though WFD provides regulation against economic interests of HP installations the lack of data (hydro-morphological, physicochemical, biological) in Greece make river basin management, planning of measures and establishing of monitoring systems for heavily modified surface water almost impossible. In Greece's report on WFD implementation uncertainties are mentioned in general in most RBDs concerning the HMWB/AWB designation process, due to the lack of relevant monitoring data [11].

According to data of the Working Document Report on the implementation of the Water Framework Directive River Basin Management Plans, Greece has not yet distinctly defined good ecological potential (GEP) and Greek authorities, given the lack of methodologies, define GEP as equal to Good Ecological Status (GES). This is implausible from the point of view of the WFD [17] and an underlying difficulty is the lack of assessment methods which are sensitive to hydromorphological modifications.

\section{Conclusions}

Given the fact that hydroelectricity accounted for about 23\% of total Greek utility-scale renewable electricity generation it appears to be an attractive, sustainable alternative to conventional energy sources that may assist in the achievement of key performance indicators related to EU commitments to the Paris Agreement.

In this respect, WFD is a reliable tool to minimize environmental impacts of HP, provides the necessary legal means to solve potential discrepancies between hydropower utilisation, water protection and ensure good ecological potential of HMWB and contribute towards the harmonization of national legislations across the EU irrespectively of certain technical and, or physical characteristics of hydropower facilities.

Greece should develop concrete methodologies to address hydro-morphological pressures and provide a clear frame for the designation of HMWB in Greek legislation in accordance with WFD. 
Given the absence of a central body to implement a water resources management strategy despite harmonization of Greek legislation with the Community Framework Directive 2000/60 / EC may cause the lack of development of GEP and impede further renewable energy substitution and watercourses preservation.

\section{References}

1. European Environment Agency (EEA). Adaptation challenges and opportunities for the European energy system: Building a climate resilient low carbon energy system. EEA Report No 01/2019; pp.37-38

2. Farmaki, P. M. Analysis of the implementation of full cost recovery of water services and water pricing in Greece under the provisions of the Water Framework Directive 2000/60/EC. Focusing on the Legal Aspect. Journal of Economic and Finance IOSR (IOSR-JEF) 2018, 9, (1), 30-39, doi: 10.9790/5933-0901033039.

3. Murray, W.M.; The ancient Dam of the Mytikas Valley, American Journal of Archeology 1984, 88, 195-203, doi: $10.2307 / 504995$

4. Koutsoyiannis, D.; Zarkadoulas, N.; Angelakis, A.; Tchobanoglous, G. Urban Water Management in Ancient Greece: Legacies and Lessons. J water resour plan man-asce. 2008, 134:1(45) doi:10.1061/(ASCE)0733$\underline{9496}$

5. Greek Committee on Large Dams. The dams of Greece, available on line http://www.eeft.gr/Fragmata Elladas 201311.pdf (accessed on 3 November 2020)

6. Directive 2000/60/EC of the European Parliament and of the Council of 23 October 2000 establishing a framework for Community action in the field of water policy 2000, Official Journal L 327, 22/12/2000 p. $0001-0073$

7. Case C-461/13: Judgment of the Court (Grand Chamber) of 1 July 2015 (request for a preliminary ruling from the Bundesverwaltungsgericht - Germany) - Bund für Umwelt und Naturschutz Deutschland e.V. v Bundesrepublik Deutschland (Reference for a preliminary ruling - Environment - EU action in the field of water policy - Directive 2000/60/EC - Article 4(1) - Environmental objectives relating to surface waters - Deterioration of the status of a body of surface water - Project for the development of a navigable waterway - Obligation of the Member States not to authorise a project that may cause a deterioration of the status of a body of surface water - Decisive criteria for determining whether there is a deterioration of the status of a body of water) 2015, OJ C 294, 7.9.2015, p. 3-4

8. European Commission, European Commission Guidance on the requirements for hydropower in relation to EU Nature legislation Luxembourg: Publications Office of the European Union, available on line https://ec.europa.eu/environment/nature/natura2000/management/docs/hydro final june_2018 en.pdf (accessed on 2 November 2020)

9. River Basin Management Plans. Available online http://wfdver.ypeka.gr/en/management-plansen/legislation-en/ (accessed on 28 October 2020)

10. Farmaki, P. M.; Tranoulidis A. Water policy in Greece: management and pricing under the provisions of the European water framework directive 2000/60/EC. In Proceedings of the CBU international conference on innovations in science and education Prague, Czech Republic March 21-23, 2018.

11. European Commission, COMMISSION STAFF WORKING DOCUMENT Report on the implementation of the Water Framework Directive River Basin Management Plans Member State: GREECE Accompanying the document COMMUNICATION FROM THE EUROPEAN COMMISSION TO THE EUROPEAN PARLIAMENT AND THE COUNCIL The Water Framework Directive and the Floods Directive: Actions towards the 'good status' of EU water and to reduce flood risks Brussels. 9.3.2015 SWD(2015) 54 final Available online https://op.europa.eu/en/publication-detail/-/publication/3470c661-c665-11e4-bbe101aa75ed71a1/language-en (accessed on 20 October 2020)

12. Kanakoudis, V.; Tsitsifli, S.; Azzariadi, T. Overview of the River Basin Management Plans developed in Greece under the context of the Water Framework Directive 2000/60/EC focusing on the economic analysis. Water Resources Management, 2015. 29, 3149-3174.

13. Grizzetti B.; Lanzanova D.; Liquete C.; Reynaud A.; Cardoso A.C. Assessing water ecosystem services for water resource management. Environmental Science \& Policy, 2016, 61, 194-203. https://doi.org/10.1016/j.envsci.2016.04.008

14. Lindström A.; Ruud, Audun. Who's Hydropower? From Conflictual Management into an Era of Reconciling Environmental Concerns; a Retake of Hydropower Governance towards Win-Win Solutions?. Sustainability, 2017. 9(7), 1262; https://doi.org/10.3390/su9071262 
15. International Hydropower Association IHA. 2018. Hydropower Status Report Available online https://www.hydropower.org/publications/2018-hydropower-status-report (accessed on 15 October 2020)

16. Askari M.; Mirzaei M. A. V.; Mirhabibi M.; Dehghani P. Hydroelectric Energy Advantages and Disadvantages. American Journal of Energy Science. 2015, 2,17-20.

17. Kampa E.; Bussettini M.; Döbbelt-Grüne, S.; Bund W.; Köller-Kreimler, V.; Vartia K.; \& Brooke J.; Halleraker J.; Wann M.; Mair R.; Boughaba J. Guidance Document No.37. Steps for defining and assessing ecological potential for improving comparability of Heavily Modified Water Bodies. European Commission Common Implementation Strategy for the Water Framework Directive (2000/60/CE), 2020. (2019). Available online https://www.ecologic.eu/sites/files/publication/2020/guidance-no-37-steps-defining-and-assessingecological-potential-for-improving-comparability-hmwbs.pdf (accessed on 10 October 2020)

(C) 2020 by the authors; licensee MDPI, Basel, Switzerland. This article is an open access article distributed under the terms and conditions of the Creative Commons by Attribution (CC-BY) license (http://creativecommons.org/licenses/by/4.0/). 